\title{
Eco-Efficiency of Hazardous Waste Treatment
}

\author{
Ekaterina Todorova $^{1}$, Savina Brankova ${ }^{1}$ \\ University of Forestry, Sofia, Bulgaria ${ }^{1}$
}

\begin{abstract}
The environmentally sound management of hazardous waste is an especially topical issue, closely related to the protection of environment and human health. The choice of Best Available Techniques (BAT) for treatment of hazardous waste lies at the base of circular economy and sustainable development. The aim of this article is to calculate the eco-efficiency of various hazardous waste treatment methods, based on international standard ISO 14045:2012. Proper methods for treatment of hazardous waste can be identified through their ecological efficiency, which is a prerequisite not only for reducing the impact of this group of waste on the environment, but also for their transformation into energy and raw material resources.
\end{abstract}

Keywords: Eco-Efficiency, Waste Management, Hazardous Waste, Waste Treatment

\section{INTRODUCTION}

The concept of eco-efficiency brings together the essential components - economic \& environmental progress, which are necessary for sustainable development [4].

Eco-efficiency is being increasingly applied in waste management, including management of hazardous waste. This group of waste poses a risk to human health and environment. The rapid rate of their generation determines the need of finding appropriate instruments for minimizing their generation, disposal and recovery. Nature and properties of hazardous waste make them a subject of more strict management regime and their treatment methods have their peculiarities. Different technical solutions provide a variety of options, and choice requires specific knowledge to achieve expediency and sustainability. The purpose of this article is to determine the eco-efficiency of hazardous waste recycling, thermal and disposal methods, based on actual plants.

\section{LITERATURE REVIEW}

Eco-Efficiency Assessment (EEA), based on International Standard ISO 14045:2012, is a quantitative management tool, which enables the study of environmental impacts of a product system [8].

Eco-efficiency assessment is based on many Life Cycle Assessment (IAC) principles, as prescribed by other International Standards (ISO 14040, ISO 14044) [6, 7, 19]. An eco-efficiency assessment comprises five phases:

- $\quad$ goal and scope definition

- $\quad$ environmental assessment

- $\quad$ product system value assessment

- $\quad$ quantification of eco-efficiency

- $\quad$ interpretation (including quality assurance)

EEA can be reliable quantitative estimate if performed in its 5 phases [3].

\section{METHODOLOGY}

Efficiency shows the relation between goals and achieved result. The higher rate of goals is achieved, the more effective are the actions. In eco-efficiency formula are included two indicators - economic value and environmental impact [1,5]:

Eco-efficiency = Economic value/Environmental impact

Economic value

$\overline{\text { Economic value }}=$ Function/Expenses [12]

When the evaluated system accomplishes its function, it can be assumed that the function is $=1$ and then:

Economic value $=1 /$ expenses, BGN $^{-1}$.

There are different ways of evaluating value of product system as it may cover different value aspects - functional, monetary and other values.

Environmental impact

High environmental, social and economic costs, resulting from current consumption of resources, require promotion and implementation of Pan-European strategy for use of resources, starting by measuring of indicators for five types of 


\section{International Advanced Research Journal in Science, Engineering and Technology}

Vol. 6, Issue 2, February 2019

resource footprint: land [ha], materials [t], water [1], greenhouse gas emissions [eqv. $\left.\mathrm{CO}_{2}\right]$ and energy [kWh/t and/or $\mathrm{kJ} / \mathrm{t}][14]$.

When performing bio-economic analysis by the "Pollution, Protection, Payment" approach [2], it is assumed that coefficients of eco-technologies turn 1 when:

- $\quad$ Production capacity installation is close to the actual;

- $\quad$ During the process, treated waste is completely transformed into products;

- $\quad$ Efficiency of treatment plant turns to 1;

- Waste materials with air and water emissions comply with legal requirements and BAT for permissible standards.

- In order to calculate eco-efficiency of various waste treatment methods it is made a quantitative characterization of generated hazardous waste for the 2010-2014 period on the territory of different towns in Bulgaria [16].

\section{ECO-EFFICIENCY OF RECYCLING OF HAZARDOUS WASTE}

There are methods for recycling of two types of hazardous waste in Bulgaria - lead-acid batteries and accumulators and cast iron (casting molds).

Recycling of hazardous waste does not require use of additional land; in recycling of metals it has been established that from $1 \mathrm{t}$ of waste metal is produced $1 \mathrm{t}$ of metal as a product; there are no changes in cost norms of water and electricity; in recycling there are no changes in greenhouse gas emissions.

It is assumed that expenses are equal to market price of waste.

For the purposes of this study, is requred acess to public information by the Executive Environment Agency (EEA) in Sofia, Bulgaria about quantities of hazardous waste generated for the period 2010-2014 in four areas in Bulgaria Sofia-city, Sofia-region, Pernik and Kustendil (Table I).

Table I Average Value of Some Recycled Materials [13, 15, 17]

\begin{tabular}{|l|l|l|l|l|}
\hline \multicolumn{1}{|c|}{ Area } & \multicolumn{2}{c|}{ Lead accumulators } & \multicolumn{2}{c|}{ Iron (cast iron, casting molds) } \\
\hline & Quantity (t/y) & Material value (BGN/y) & Quantity (t/y) & Material value (BGN/y) \\
\hline Sofia-city & 350 & 480200 & 16 & 4352 \\
\hline Sofia-region & 35 & 48020 & 5 & 1360 \\
\hline Pernik & 17 & 23324 & 0 & 0 \\
\hline Kustendil & 15 & 20580 & 0 & 0 \\
\hline Total & 417 & 572124 & 21 & 5712 \\
\hline
\end{tabular}

Eco-efficiency is calculated, based on formula, mentioned above (Table II).

Table III Eco-Efficiency of Recycling Methods For Some Types of Waste

\begin{tabular}{|l|l|l|l|}
\hline \multicolumn{1}{|c|}{ Waste } & $\begin{array}{c}\text { Economic value } \\
\left(\mathbf{B G N}^{-\mathbf{1}}\right)\end{array}$ & $\begin{array}{c}\text { Environmental } \\
\text { impact }\end{array}$ & $\begin{array}{c}\text { Eco-efficiency } \\
\left(\mathbf{B G N}^{\mathbf{1}}\right)\end{array}$ \\
\hline Lead accumulators & $1,7.10^{-6}$ & 1 & $1,7.10^{-6}$ \\
\hline Iron (cast iron, casting molds) & $1,7.10^{-4}$ & 1 & $1,7.10^{-4}$ \\
\hline
\end{tabular}

\section{ECO-EFFICIENCY OF THERMAL TREATMENT OF HAZARDOUS WASTE}

The most commonly used thermal methods in world practice are incineration, pyrolysis, gasification, plasma technologies, as well as combination of these, namely plasma gasification $[9,14]$.

Heat, generated by exploitation of incineration plants or co-incineration plants, is being utilized. Incineration plants are designed, constructed and/or operated in such way that the content of harmful substances in exhaust gases does not exceed the relevant emission limit values. For this purpose various methods and techniques for the treatment of waste gases, which reduce level of harmful substances in them are applied.

Based on mathematical logic that the higher the denominator in eco-efficiency formula is, the lower the eco-efficiency is, it is assumed that the value of environmental impact of landfill is 1.5. Considering the waste management hierarchy, this means that the most favorable method that does not impact on the environment is recycling with factor 1 , and the most unfavorable is disposal with impact factor 1.5. For environmental impact of thermal methods it is taken as follows: 


\section{International Advanced Research Journal in Science, Engineering and Technology}

Vol. 6, Issue 2, February 2019

- $\quad$ For plasma gasification, where there is practically no waste, but only products - impact value 1

- $\quad$ For gasification, where a product is produced and amount of waste is negligible - impact value 1.1

- $\quad$ For pyrolysis, where type and quantity of products and waste vary depending on the temperature - impact value

1.2

For incineration with energy recovery, but released waste gases and solid waste - 1.3

For incineration without energy recovery -1.4

The costs of gasification in electricity generation are indicated and eco-efficiency is calculated on the basis of formula, mentioned above (Table III, Table IV).

Table IIIII Average Cost Per Tonne Waste Treated by Thermal Methods [18]

\begin{tabular}{|l|l|l|}
\hline \multicolumn{1}{|c|}{ Area } & \multicolumn{1}{|c|}{$\begin{array}{c}\text { Quantity } \\
(\mathbf{t} / \mathbf{y})\end{array}$} & \multicolumn{1}{|c|}{$\begin{array}{c}\text { Gasification costs of electricity } \\
\text { production (BGN/y) }\end{array}$} \\
\hline Sofia-city & 110 & 6600 \\
\hline Sofia-region & 321 & 19260 \\
\hline Pernik & 2179 & 130740 \\
\hline Kustendil & 35425 & 2125500 \\
\hline Total & 38035 & 2282100 \\
\hline
\end{tabular}

Table IVV Eco-Efficiency of Thermal Method of Hazardous Waste Treatment

\begin{tabular}{|l|l|l|l|}
\hline Method & Economic value $\left(\mathbf{B G N}^{-1}\right)$ & Environmental impact & Eco-efficiency $\left(\mathbf{B G N}^{-1}\right)$ \\
\hline Gasification & $0,4 \cdot 10^{-6}$ & 1,1 & $0,4 \cdot 10^{-6}$ \\
\hline
\end{tabular}

\section{ECO-EFFICIENCY OF DISPOSAL OF HAZARDOUS WASTE}

Waste landfills must be located and designed so as to avoid contamination of air, soil, groundwater and/or surface water and to ensure effective collection of the infiltrate [10].

According to Bulgarian legislation for disposal of waste deductions for waste landfilling are paid [11]. It is assumed that expenditure deductions are sufficient to accomplish environmentally sound operation and post-operational control of landfill, where relevant hazardous waste is disposed (Table V).

Table V Average Cost Per Tonne Disposed Waste in 2017 and 2020

\begin{tabular}{|l|l|l|l|}
\hline \multicolumn{1}{|c|}{ Area } & \multicolumn{1}{|c|}{$\begin{array}{c}\text { Quantity } \\
(\mathbf{t} / \mathbf{y})\end{array}$} & $\begin{array}{c}\text { Expenditure deductions } \\
\mathbf{2 0 1 7}(\mathbf{B G N} / \mathbf{y})\end{array}$ & $\begin{array}{c}\text { Expenditure deductions } \\
\mathbf{2 0 2 0}(\mathbf{B G N} / \mathbf{y})\end{array}$ \\
\hline Sofia-city & 1 & 35 & 95 \\
\hline Sofia-region & 9490 & 332150 & 901550 \\
\hline Pernik & 608 & 21280 & 57760 \\
\hline Kustendil & 21800 & 763000 & 2071000 \\
\hline Total & 31899 & 1116465 & 3030405 \\
\hline
\end{tabular}

Disposal is the most unacceptable alternative of waste treatment in terms of the lack of opportunity to use waste as energy and raw material resource. At the same time, in implementation of regulatory requirements [10] no negative impact on the environment is expected. The main natural resource, used in this method, is land, which has changed its purpose, and through land reclamation stages can fit into the landscaping of landfill area. Due to above mentioned reasons the environmental impact factor for disposal of hazardous waste is assumed 1.5 (Table VI).

Table VI Eco-Efficiency of Landfill in 2017 and 2020

\begin{tabular}{|l|l|l|l|}
\hline Year & Economic value $\left(\mathbf{B G N}^{-1}\right)$ & Environmental impact & Eco-efficiency $\left(\mathbf{B G N}^{-\mathbf{1}}\right)$ \\
\hline 2017 & $0,8 \cdot 10^{-6}$ & 1,5 & $0,5.10^{-6}$ \\
\hline 2020 & $0,3 \cdot 10^{-6}$ & 1,5 & $0,2.10^{-6}$ \\
\hline
\end{tabular}

Increasing of expenditure deductions in the period 2017 - 2020 leads to a decrease in ecological efficiency of disposal as a waste treatment method. 


\section{International Advanced Research Journal in Science, Engineering and Technology}

Vol. 6, Issue 2, February 2019

\section{CONCLUSION}

Obtained results show that at recycling of waste eco-efficiency depends in significant extent on economic value of recycling process (respectively of the amount of recycled waste) and does not depend on environmental impact The driving force in building of circular economy is increasing of cost for disposal. Recycling, as part of circular economy costs money, but collection and recycling of one tonne of recyclable materials is far more economical than disposal of one tonne of waste.

The average eco-efficiency of recycling is $1,7.10^{-5}$, compared to eco-efficiency of landfilling for the same period $0,5.10^{-6}$. Calculations for eco-efficiency of thermal methods $\left(0.4 .10^{-6}\right)$ show close to disposal values for $2017\left(0.5 .10^{-6}\right)$, but with increasing cost of landfilling, thermal methods will become more appealing not only in terms of their environmental friendliness, but also in terms of their economic efficiency, which for disposal in 2020 is $0.2 .10^{-6}$.

\section{ACKNOWLEDGMENT}

Article is developed by project BG05M2OP001-1.002-0019-C 01 for building and development of Competence Center "Clean technologies for sustainable environment - water, waste, energy for circular economy" (Clean\&Circle), funded by Operational Programme "Science and Education for Smart Growth".

\section{REFERENCES}

[1]. A. Eik, "Eco-efficiency of Waste Management", Norwegian Univercity of Science and Technology Trondheim, Norway, 2005.

[2]. E. Todorova and I. Dombalov, Exercise Guide of Solid Waste Treatment Technologies, Ecotech Consult Ltd, Sofia, Bulgaria, 2005.

[3]. E. Todorova, V. Kyoseva and I. Dombalov, "Necessary System for Evaluation of Ecological Efficiency of Investment Proposals", Journal of Balkan Ecology, 2016, vol.19.

[4]. H. Verfaille and R. Bidwell, 2000, "Measuring ecoefficiency", A guide to reporting company performance, 2000.

[5]. H. Yuan, Z. Huang and P. Xu, "A Framework for Eco-efficiency of C\&D Waste Management”, Elsevier, 2016.

[6]. ISO 14040:2006 Environmental Management - Life Cycle Assessment - Principles and Framework.

[7]. ISO 14044:2006 Environmental Management - Life Cycle Assessment - Requirements and Guidelines.

[8]. ISO 14045:2012 Environmental Management - Eco-efficiency Assessment of Product Systems - Principles, Requirements and Guidelines.

[9]. K. Moustakas, M. Loizidou, "Solid Waste Management through the Application of Thermal Methods", In Tech, Greece, 2010.

[10]. Ordinance № 6 from 27 August 2013 on the conditions and requirements for construction and operation of landfills and other facilities and installations for recovery and disposal of waste.

[11]. Ordinance № 7 from 19 December 2013 on the order and way of calculating and determining the amount of collateral deductions required for landfill.

[12]. P. Stanchev, Autoreferate of dissertation work "Eco-efficiency of local water supply and sewerage systems", University of Architecture Civil Engineering and Geodesy, Bulgaria, 2016

[13]. Prices on Hardgreymetals. [Online]. Available: http://hardgreymetals.com/

[14]. Solid Waste Treatment and Utilization Methods. Ecology \& Infrastructure, https://www.ecology-and-infrastructure.bg/bg/broi-3/6/12/, 2014.

[15]. The Bgscrap website. [Online]. Available: http://bgscrap.com/

[16]. The EEA website. [Online]. Available: http:// eea.government.bg/

[17]. The Scrap-bg website. [Online]. Available: http://scrap-bg.com/

[18]. The Sierraenegycorp website. [Online]. Available: http://sierraenergycorp.com/

[19]. W. Li, et al., "Life Cycle Assessment of the Environmental Impacts of Typical Industrial Hazardous Waste Incineration in Eastern China", Aerosol and Air Quality Research, China, 2015. 